Rosenthal, Y., Holbourn, A.E., Kulhanek, D.K., and the Expedition 363 Scientists

Proceedings of the International Ocean Discovery Program Volume 363

publications.iodp.org

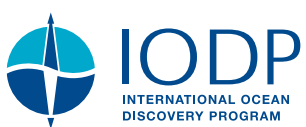

https://doi.org/10.14379/iodp.proc.363.201.2020

\section{Data report: revised composite depth scale and splice for IODP Expedition 363 Site U1483'}

Li Gong, ${ }^{2}$ Julia Lübbers, ${ }^{2}$ Sebastian Beil, ${ }^{2}$ and Ann Holbourn ${ }^{2}$
Contents
1 Abstract
1 Introduction
2 Material and methods
2 Results
7 Acknowledgments
7 References

Keywords: International Ocean Discovery Program, IODP, JOIDES Resolution, Expedition 363, Western Pacific Warm Pool, Site U1483, Northwest Australian margin, composite depth scale, revised composite depth scale, shipboard composite splice, revised composite splice, XRF core scanning

\begin{abstract}
The shipboard sediment splice of International Ocean Discovery Program Expedition 363 Site U1483, drilled in 1733 m water depth on the Scott Plateau off Northwest Australia, was primarily based on a composite of the magnetic susceptibility records at 2.5 $\mathrm{cm}$ resolution from three holes drilled at this site. We performed Xray fluorescence (XRF) core scanning at $2 \mathrm{~cm}$ intervals with overlaps of $\sim 1-2 \mathrm{~m}$ at splice tie points and used these new data to verify the tie points along the original splice from 0 to $211.53 \mathrm{~m}$ core composite depth below seafloor (CCSF). Based on the XRF records, we revised the position of three original tie points and present a revised composite depth scale for Site U1483. These revisions resulted in shifts of up to $94 \mathrm{~cm}$ relative to the original shipboard offsets and a continuous section extending down to $211.62 \mathrm{~m}$ revised core composite depth below seafloor ( $r-C C S F)$.
\end{abstract}

\section{Introduction}

International Ocean Discovery Program (IODP) Site U1483 $\left(13^{\circ} 5.24^{\prime} \mathrm{S}, 121^{\circ} 48.25^{\prime} \mathrm{E} ; 1733 \mathrm{~m}\right.$ water depth) is located on the Scott Plateau at the northwest margin of the northeast-trending Browse Basin, which lies between the onshore Kimberley Basin and the Scott Plateau along the northwest Australian margin (Rosenthal et al., 2018b) (Figure F1).

Three holes were cored at Site U1483 using the advanced piston corer (APC) system to 290 meters below seafloor (mbsf) (Rosenthal et al., 2018b). The succession recovered at Site U1483 consists of pelagic and hemipelagic lower Pliocene to recent sediment. Magnetic susceptibility (MS) was used to create the original shipboard splice and composite depth scale at Site U1483. Whole-Round Multisensor Logger (WRMSL) gamma ray attenuation bulk density and natural gamma radiation data were helpful in making correlations,
Figure F1. Location of Site U1483 (modified from Rosenthal et al., 2018a).

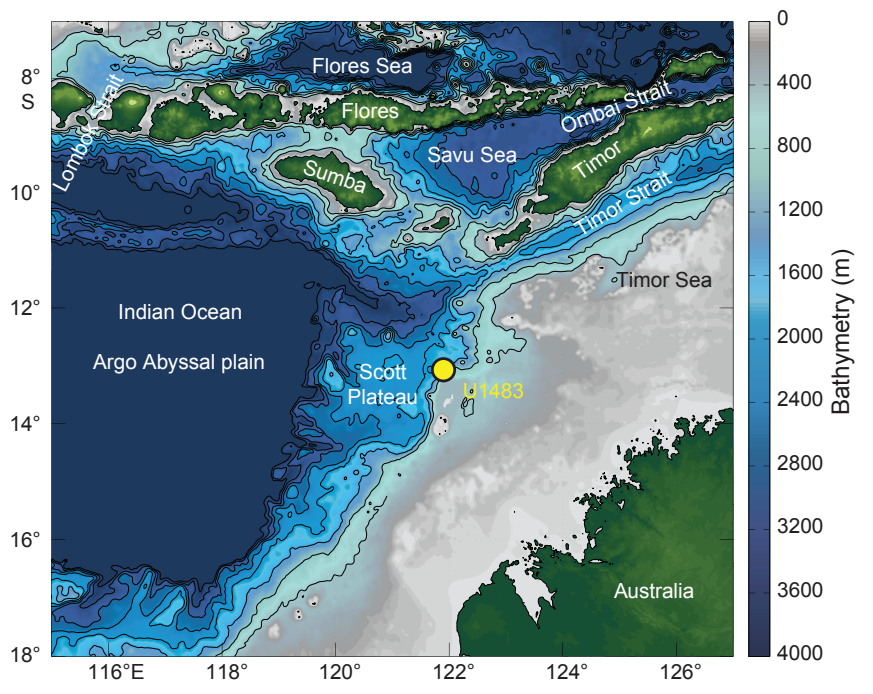

but the MS data provided the most consistent means of correlation for splice construction (Rosenthal et al., 2018b). The original splice of Site U1483 consists of two intervals, one from 0 to $211.5 \mathrm{~m}$ core composite depth below seafloor (CCSF) and the other from 239.8 to $266.8 \mathrm{~m}$ CCSF. No splice was established between 211.5 and 239.8 $\mathrm{m}$ CCSF and below $266.8 \mathrm{~m}$ CCSF because of soft-sediment deformation. Estimation of offsets for cores between deformed intervals is detailed in Rosenthal et al. (2018b). Here, we present a revision of splice tie points over the interval from 0 to $211.5 \mathrm{~m}$ CCSF based on new, high-resolution X-ray fluorescence (XRF) core scanning elemental data.

\footnotetext{
${ }^{1}$ Gong, L., Lübbers, J., Beil, S., and Holbourn, A., 2020. Data report: revised composite depth scale and splice for IODP Expedition 363 Site U1483. In Rosenthal, Y., Holbourn, A.E., Kulhanek, D.K., and the Expedition 363 Scientists, Western Pacific Warm Pool. Proceedings of the International Ocean Discovery Program, 363: College Station, TX (International Ocean Discovery Program). https://doi.org/10.14379/iodp.proc.363.201.2020

${ }^{2}$ Institute of Geosciences, Christian-Albrechts University, Germany. Correspondence author: li.gong@ifg.uni-kiel.de MS 363-201: Received 19 November 2019 . Accepted 29 April 2020 • Published 18 June 2020

This work is distributed under the Creative Commons Attribution 4.0 International (CC BY 4.0) license. (cc) BY
} 


\section{Material and methods}

The shipboard composite depth scale and splice for Site U1483 were revised using high-resolution XRF core scanning elemental data ( $2 \mathrm{~cm}$ intervals) obtained with the 2nd Generation Avaatech XRF Core Scanner at the Institute of Geosciences, Christian-Albrechts University Kiel (Germany) (Table T1). The XRF core scanner is equipped with an XR-100CR detector from Amptek and Oxford Instruments 50W XTF5011 X-ray tube with rhodium target material. Before scanning, the archive halves were equilibrated at room temperature and a thin layer of sediment was removed from the top to obtain a fresh, even surface for scanning. We scanned at 2 $\mathrm{cm}$ intervals along the shipboard splice with approximately 1-2 $\mathrm{m}$ overlap at splice tie points. Scanning was performed with $10 \mathrm{kV}, 750$ $\mu \mathrm{A}, 10 \mathrm{~s}$ acquisition time, and no filter on archive halves covered with a $4 \mu \mathrm{m}$ thick Chemplex Prolene Thin-Film foil to prevent contamination of the XRF detector. We used a crosscore slit size of 1.2 $\mathrm{cm}$ and a downcore slit size of $1 \mathrm{~cm}$. Raw X-ray spectra were converted into area counts using the iterative least-square software package WIN_AXIL from Canberra Eurisys and a core-specific model. A total of 15 elements (Al, Si, P, S, Cl, K, Ca, Ti, Cr, Mn, Fe, $\mathrm{Co}, \mathrm{Rb}, \mathrm{Sr}$, and $\mathrm{Rh}$ ) were analyzed. Here, we use the logarithmic ratio of calcium, which is primarily biogenic, against typical terrigenous elements $(\mathrm{Al}+\mathrm{K}+\mathrm{Ti}+\mathrm{Fe})$ because this ratio shows a distinct signal with high-amplitude variability. Logarithmic ratios of elemental counts used for data analysis provide the most easily interpretable signal of chemical variability and minimize measurement artifacts specific to XRF core scanning (Weltje and Tjallingii, 2008).

Table T1. X-ray fluorescence core scanning log $(\mathrm{Ca} /[\mathrm{Al}+\mathrm{K}+\mathrm{Ti}+\mathrm{Fe}])$ data for revised intervals of the splice, Site U1483. Download table in CSV format.

\section{Results}

The revised composite depth scale and splice cover the complete interval from $14.17 \mathrm{~m}$ revised core composite depth below seafloor ( $\mathrm{r}$-CCSF) to the end of the first spliced interval at $211.62 \mathrm{~m}$ $\mathrm{r}$-CCSF. The higher resolution XRF scanning elemental data with 1-2 $\mathrm{m}$ overlaps at the original tie points allowed us to adjust the position of three tie points between Sections 363-U1483C-2H-6 and 363-U1483A-17H-2 (Table T2). The MS data along the revised splice and across the three tie points are shown in Figure F2 and Figure F3A, F3C, and F3E, respectively. Table T3 summarizes the changes to individual offsets along the splice.

The first revised tie point at $14.17 \mathrm{~m} \mathrm{r}$-CCSF connects Section 363-U1483C-2H-6, $77.5 \mathrm{~cm}$ (14.58 mbsf), to Section 363-U1483B$3 \mathrm{H}-1,76.4 \mathrm{~cm}$ (12.26 mbsf) (Figure F3A, F3B). We adjusted the original tie point by adding $1 \mathrm{~cm}$ at the base of the spliced interval in Section 363-U1483C-2H-6 and $93 \mathrm{~cm}$ at the top in Section 363U1483B-3H-1. These changes result in the addition of $94 \mathrm{~cm}$ to the splice. The second revised splice tie point at $135.64 \mathrm{~m} \mathrm{r}$-CCSF, which corresponds to a distinctive ash layer, connects Section 363U1483C-14H-6, $126.4 \mathrm{~cm}$ (128.64 mbsf), to Section 363-U1483A$14 \mathrm{H}-3,78 \mathrm{~cm}$ (126.3 mbsf) (Figure F3C, F3D). We selected the base of the ash layer as the new tie point, adding $45 \mathrm{~cm}$ at the base of the spliced interval in Section 363-U1483C-14H-6 and deleting $101 \mathrm{~cm}$ from the top of the spliced interval in Section 363-U1483A-14H-3. This revision results in the removal of $56 \mathrm{~cm}$ from the splice. The third tie point at $166.62 \mathrm{~m} \mathrm{r}$-CCSF was adjusted by correlating Section 363-U1483B-17H-6, $132 \mathrm{~cm}$ (153.17 mbsf), to Section 363U1483A-17H-2, $86 \mathrm{~cm}$ (153.43 mbsf). For this correlation, we deleted $17 \mathrm{~cm}$ from the bottom of the splice interval in Section 363U1483B-17H-6 and deleted $12 \mathrm{~cm}$ from the top of Section 363U1483A-17H-2 (Figure F3E, F3F). This revision results in the removal of $29 \mathrm{~cm}$ from the splice. These three revisions resulted in the addition of $9 \mathrm{~cm}$ to the original shipboard splice (Table T2).

Table T2. Revised splice interval table, Site U1483. Download table in CSV format. 
Figure F2. Whole-Round Multisensor Logger magnetic susceptibility (MS) on revised composite depth scale, Holes U1483A-U1483C. Upper panel shows MS splice constructed by combining data from all holes. Red $=$ Hole U1483A, blue $=$ Hole U1483B, green $=$ Hole U1483C, orange triangles $=$ original tie points, black triangles $=$ revised tie points. A. 0-50 m r-CCSF. B. 50-100 m r-CCSF. (Continued on next 2 pages.)
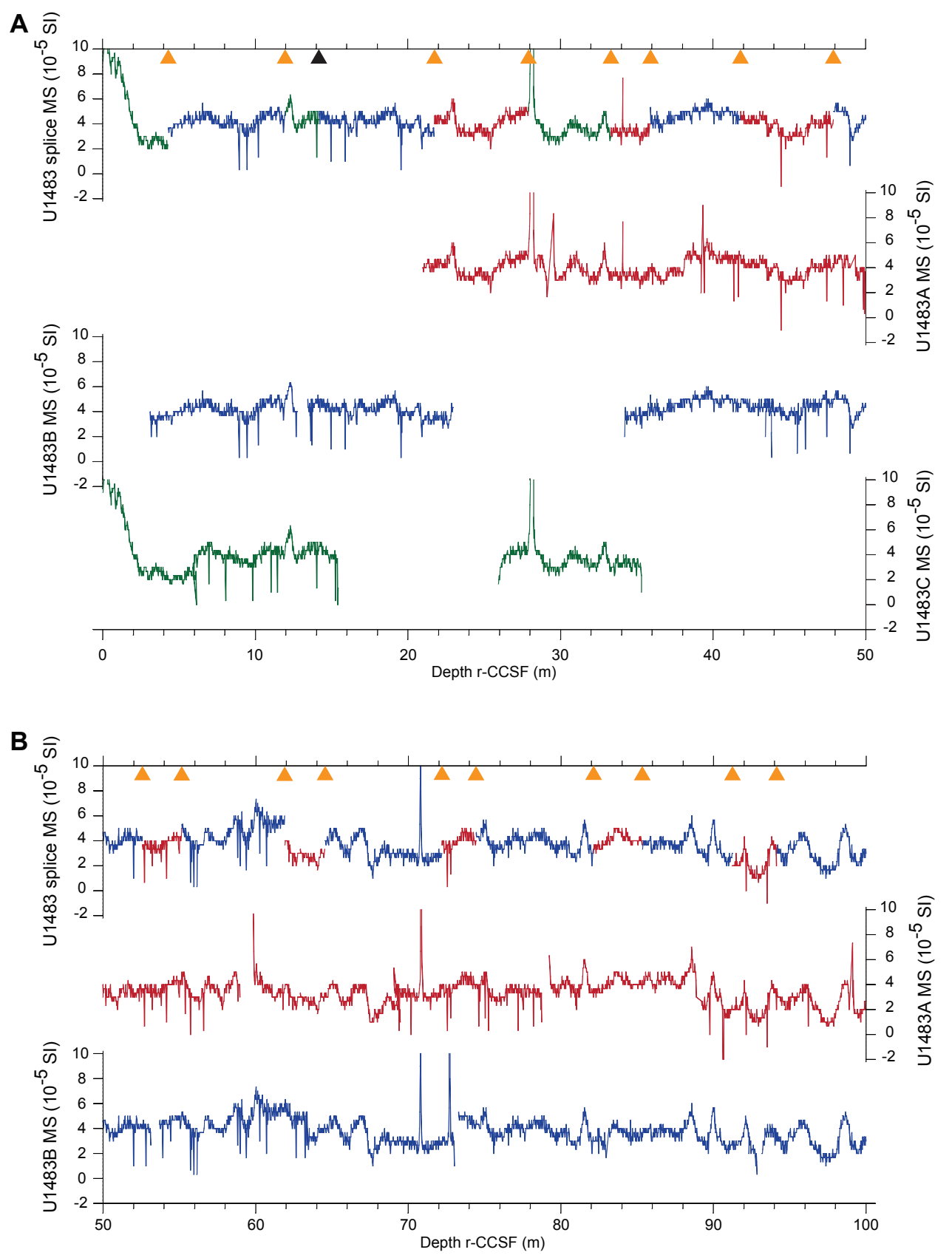
Figure F2 (continued). C. 100-150 m r-CCSF. D. 150-200 m r-CCSF. (Continued on next page.)
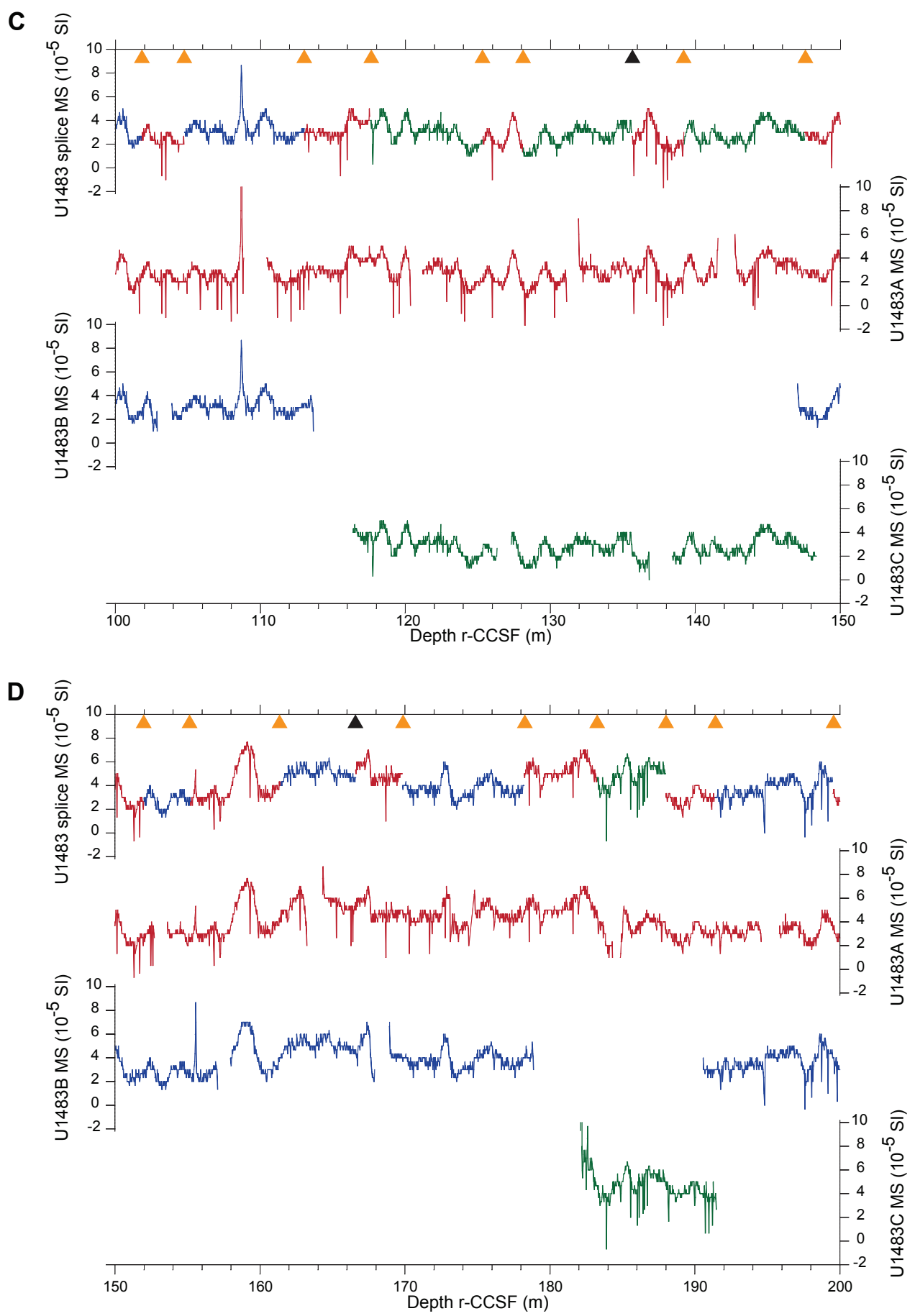
Figure F2 (continued). E. 200-212 m r-CCSF.

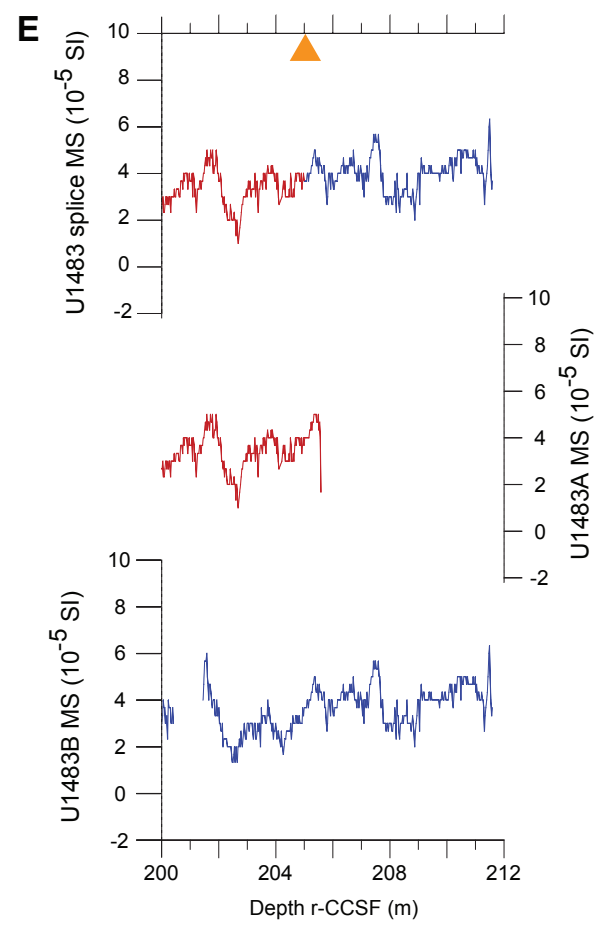


Figure F3. Whole-Round Multisensor Logger (WRMSL) magnetic susceptibility (MS) and X-ray fluorescence (XRF) scanning log (Ca/[Al $+\mathrm{K}+\mathrm{Ti}+\mathrm{Fe}])$ on revised composite depth scale for revised intervals of the splice, Holes U1483A-U1483C. Red $=$ Hole U1483A, blue $=$ Hole U1483B, green $=$ Hole U1483C, black triangles $=$ revised tie points. A, B. 10-20 m r-CCSF. C, D. 130-140 m r-CCSF. E, F. 160-170 m r-CCSF. XRF data are given in Table T1.
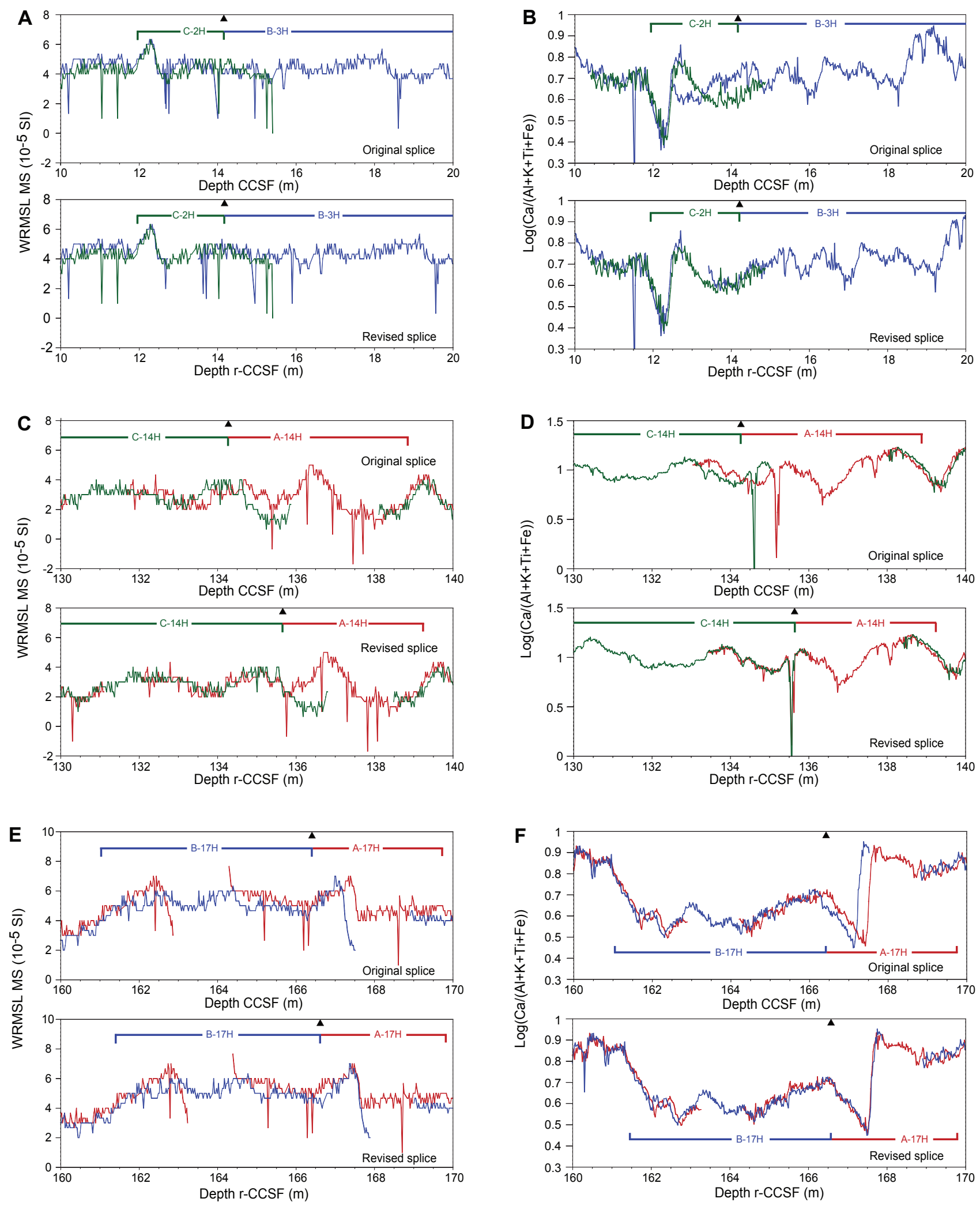
Table T3. Revised affine table, Site U1483. Download table in CSV format.

\section{Acknowledgments}

This research used samples and data provided by the International Ocean Discovery Program (IODP) and was funded by the German Research Foundation (DFG Grant Number HO 2311/5) and a studentship from the China Scholarship Council (CSC). We thank the IODP Expedition 363 shipboard scientists and the crew of the R/V JOIDES Resolution for all their efforts and dedication. We also thank Thomas Westerhold and Sietske J. Batenburg for constructive comments and Denise K. Kulhanek and Gigi Delgado for editorial support to improve the manuscript. We gratefully acknowledge Ursula Röhl and Alex Wülbers (IODP Bremen Core Repository) and Doris Maicher and Maik Lange (GEOMAR Helmholtz Centre for Ocean Research Kiel) for logistical assistance with storing and handling cores.

\section{References}

Rosenthal, Y., Holbourn, A.E., Kulhanek, D.K., Aiello, I.W., Babila, T.L., Bayon, G., Beaufort, L., Bova, S.C., Chun, J.-H., Dang, H., Drury, A.J., Dunkley
Jones, T., Eichler, P.P.B., Fernando, A.G.S., Gibson, K.A., Hatfield, R.G., Johnson, D.L., Kumagai, Y., Li, T., Linsley, B.K., Meinicke, N., Mountain, G.S., Opdyke, B.N., Pearson, P.N., Poole, C.R., Ravelo, A.C., Sagawa, T., Schmitt, A., Wurtzel, J.B., Xu, J., Yamamoto, M., and Zhang, Y.G., 2018a. Expedition 363 summary. In Rosenthal, Y., Holbourn, A.E., Kulhanek, D.K., and the Expedition 363 Scientists, Western Pacific Warm Pool. Proceedings of the International Ocean Discovery Program, 363: College Station, TX (International Ocean Discovery Program). https://doi.org/10.14379/iodp.proc.363.101.2018

Rosenthal, Y., Holbourn, A.E., Kulhanek, D.K., Aiello, I.W., Babila, T.L., Bayon, G., Beaufort, L., Bova, S.C., Chun, J.-H., Dang, H., Drury, A.J., Dunkley Jones, T., Eichler, P.P.B., Fernando, A.G.S., Gibson, K.A., Hatfield, R.G., Johnson, D.L., Kumagai, Y., Li, T., Linsley, B.K., Meinicke, N., Mountain, G.S., Opdyke, B.N., Pearson, P.N., Poole, C.R., Ravelo, A.C., Sagawa, T., Schmitt, A., Wurtzel, J.B., Xu, J., Yamamoto, M., and Zhang, Y.G., 2018b. Site U1483. In Rosenthal, Y., Holbourn, A.E., Kulhanek, D.K., and the Expedition 363 Scientists, Western Pacific Warm Pool. Proceedings of the International Ocean Discovery Program, 363: College Station, TX (International Ocean Discovery Program). https://doi.org/10.14379/iodp.proc.363.104.2018

Weltje, G.J., and Tjallingii, R., 2008. Calibration of XRF core scanners for quantitative geochemical logging of sediment cores: theory and application. Earth and Planetary Science Letters, 274(3-4):423-438. https://doi.org/10.1016/j.epsl.2008.07.054 